\title{
Perencanaan Sistem Pengolahan Air Limbah Domestik Pada Daerah Aliran Sungai Cibabat, Kota Cimahi
}

\author{
Mochammad Azhar Rais Alfaroby ${ }^{1^{*}}$, Eka Wardhani $^{2^{*}}$ \\ ${ }^{1,2}$ Jurusan Teknik Lingkungan, Institut Teknologi Nasional (Itenas), Bandung \\ *Koresponden email: raisalfaroby08@gmail.com, ekawardhani08@gmail.com
}

Diterima : 1 Maret 2021

Disetujui: 22 Maret 2021

\begin{abstract}
The increase in population increases the need for clean water and community activities to increase and has an impact on the increase in the amount of wastewater produced. The amount of wastewater produced depends on a large number of people who require the need clean water for each existing human activity. Domestic waste management in the Cibabat watershed area of Cimahi City remains minimal, in an effort to improve the quality of the Cibabat River and support the accelerated pollution control in the Citarum watershed, which is part of the Citarum Harum program in 2018, there must therefore be a planning system for the distribution of domestic wastewater in the Cibabat watershed, Cimahi City in order to produce domestic wastewater that can be channeled and treated correctly so that it does not pollute the aquatic environment. The method used in the planning of the domestic wastewater distribution system is based on PUPR Regulation No. 04 of 2017 concerning guidelines for the implementation of the domestic wastewater management system. With the wastewater distribution network in the Cibabat River watershed, the hope is to improve water quality in the Cibabat River, Cimahi City in the planning period of the next two decades. This study will determine the type of application of an effective domestic wastewater management system adapted to the existing current conditions of the Cibabat watershed in Cimahi City.
\end{abstract}

Keywords: Cibabat River, screening, domestic waste, river management, pollution control

\begin{abstract}
Abstrak
Meningkatnya jumlah penduduk menyebabkan kebutuhan air bersih dan kegiatan masyarakat bertambah hingga berdampak pada peningkatan jumlah air limbah. Banyaknya air limbah yang ditimbulkan bergantung dari banyak jumlah populasi terhadap kebutuhan air bersih yang digunakan pada setiap kegiatan manusia. Pengelolaan limbah domestik di wilayah DAS Cibabat, Kota Cimahi masih terbilang minim sehingga perlu percepatan pengendalian pencemaran DAS Citarum yang merupakan bagian dari program Citarum Harum pada tahun 2018. Percepatan membutuhkan perencanaan sistem penyaluran air limbah domestik yang ada pada DAS Cibabat, Kota Cimahi dengan tujuan air limbah domestik yang dihasilkan dapat tersalurkan dan terolah dengan baik sehingga tidak mencemari lingkungan perairan. Metode yang digunakan dalam perencanaan sistem penyaluran air limbah domestik ini mengacu pada Permen PUPR No 04 Tahun 2017 tentang pedoman penyelenggaraan sistem pengelolaan air limbah domestik. Dengan adanya sistem penyaluran air limbah di DAS Cibabat ini diharapkan dapat memperbaiki peningkatan kualitas mutu air Sungai Cibabat, Kota Cimahi pada periode perencanaan 20 tahun ke depan. Penelitian ini akan menentukan jenis penerapan sistem pengelolaan air limbah domestik yang efektif yang disesuaikan pada kondisi eksisting DAS Cibabat, Kota Cimahi.
\end{abstract}

Kata kunci : Sungai Cibabat, penapisan, limbah domestik, pengelolaan, pengendalian pencemaran

\section{Pendahuluan}

Sungai Cibabat merupakan salah satu sungai yang berada di Kota Cimahi yang berasal dari Kabupaten Bandung Barat dan mengalir ke arah selatan Kota Cimahi yang akan bermuara ke Sungai Citarum [1]. Seiring peningkatan jumlah penduduk, industri dan fasilitas umum membuat daerah di sekitar DAS Cibabat mengalami perubahan tata guna lahan yang mengakibatkan Sungai Cibabat mengalami penurunan kualitas air oleh besarnya jumlah pencemaran limbah yang dihasilkan dari sektor domestik. [1]. Saat ini air Sungai Cibabat sudah menjadi masalah yang perlu mendapatkan perhatian serius, karena masyarakat disekitar Sungai Cibabat hilir telah dikeluhkan dengan masalah kesehatan seperti seperti kulit gatal-gatal, diare dan gangguan penyakit bawaan air lainnya [1].

Dinas Lingkungan Hidup (DLH) Kota Cimahi pada tahun 2019 telah melakukan pemantauan kondisi Sungai Cimahi dan dilakukan secara 3 kali yaitu pada bulan April, September, dan Desember [1]. 
Hasil pemantauan menyatakan daya tampung beban pencemaran Sungai Cibabat sudah melebihi batas dari daya tampungnya dan juga kondisi status mutu air Sungai Cibabat yang dikategorikan telah tercemar berat pada bagian hilir Sungai Cibabat [1]. Selain Sungai Cibabat sungai lainnya di Kota Cimahi yaitu Cibaligo, Cibeureum, dan Cisangkan mengalami permasalahan yang sama. Sungai-sungai tersebut tercemar limbah domestik dengan mutu air termasuk dalam katagori tercemar berat. Parameter yang telah melebihi daya tampungnya diantaranya $\mathrm{BOD}_{5}, \mathrm{COD}$, TSS, minyak dan lemak, Total Coliform dan Fecal Coliform. Parameter tersebut beban pencemarannya besar dan masuk ke sungai karena tidak adanya sistem pengelolaan air limbah domestik (SPALD) yang baik [2]; [3]; [4]. Hal tersebut menjadikan permasalahan dan dampak buruk terhadap kesehatan masyarakat khususnya di sekitar DAS Cibabat dan umumnya di Kota Cimahi.

Kondisi pencemaran yang terjadi memerlukan penanganan secepat mungkin diantaranya dengan melakukan penyusunan rencana induk sistem pengolahan air limbah domestik pada DAS Cibabat Kota Cimahi. Kegiatan ini merupakan suatu bagian pengendalian pencemaran air Sungai Cibabat pada sektor domestik. Langkah untuk mengetahui penerapan Sistem Pengolahan Air Limbah Domestik (SPALD) pada DAS Cibabat diperlukan suatu kajian penapisan daerah perencanaan yang mengacu pada PermenPUPR No.4/2017 tentang perencanaan SPALD [5]. Kegiatan penapisan telah dilakukan di Kota Depok dan Bekasi, dimana masing-masing penelitian menghasilkan pembagian wilayah yang dapat dilayani dengan SPALD terpusat dan setempat. Hasil penelitian yang telah dilakukan dapat membantu pemangku kependitang di Kota Depok dan Bekasi dalam memutuskan SPALD yang akan diterapkan di masing-masing kota [6]; [7]; [8].

Penelitian ini bertujuan menggambarkan kondisi eksisting DAS Cibabat dan menentukan jenis pemilihaan SPALD yang tepat sesuai dengan kondisi eksisting wilayah DAS Cibabat, Kota Cimahi dengan mengacu terhadap Peraturan Menteri Pekerjaan Umum dan perumahan Rakyat No.4 Tahun 2017 tentang penyelengaraan SPALD (Permen PUPR 4/2017) yang merupakan bagian dan rencana strategi pengendalian pencemaran air limbah DAS Cibabat pada periode tahun 2020-2040.

\section{Metode Penelitian}

Penentuan sistem pengendalian pencemaran air limbah domestik di DAS Cibabat mengacu pada kriteria yang telah diatur oleh Permen PUPR 4/2017 melalui serangkaian analisis penapisan di DAS Cibabat. Kriteria yang diatur Permen PUPR 4/2017 dalam penentuan jenis SPALD dibandingkan dengan kondisi eksisting daerah perencanaan yaitu DAS Cibabat. Penentuan jenis SPALD berdasarkan PerMenPUPR No. 4 tahun 2017 didasari pada 5 pertimbangan yang dapat dilihat pada Gambar 1. Penentuan jenis SPALD ini didasari pada 5 (lima) pertimbangan yaitu [18]:

1. Kepadatan penduduk

Kepadatan penduduk harus lebih besar dari 150 jiwa per hektar atau $>15.000 \mathrm{jiwa} / \mathrm{km} 2$ untuk bisa menggunakan SPALD-Terpusat. Jika kepadatan penduduk kurang dari angka tersebut, maka akan menggunakan SPALD-S [18].

2. Kedalaman muka air tanah

Kedalaman muka air tanah dapat dilihat dari cekungan air tanah. Dimana lapisan muka air tanah kurang dari dua meter atau kondisi air tanah sudah tercemar, maka harus menggunakan SPALD-T [18].

3. Permeabilitas tanah

Permeabilitas yang efektif yaitu $5 \times 10-4 \mathrm{~m} /$ detik dengan jenis tanah pasir halus sampai dengan pasir yang mengandung lempung [18].

4. Kemampuan Pembiayaan

Kemampuan pembiayaan dapat mempengaruhi pemilihan jenis SPALD, terutama bila kemampuan Pemerintah Daerah sanggup dalam membiayai pengoperasian dan pemeliharaan maka bisa dilakukan pengelolaan air limbah dengan cara SPALD-T [18].

\section{Kemiringan tanah}

Penerapan jaringan pengumpulan air limbah domestik sesuai jika kemiringan tanah sama dengan atau lebih dari $2 \%$ (dua persen), dan bisa menggunakan SPALD-T

6. Ketentuan khusus

Apabila pada saat penapisan ternyata suatu daerah dinyatakan menggunakan jenis pengelolaan dengan cara SPALD-S, tetapi bisa melakukan peningkatan kualitas pengelolaan, maka dengan pertimbangan kemiringan lahan lebih besar dari pada $2 \%$ maka bisa digunakan jenis SPALD-T skala perkotaan, jika tidak pilihan lainnya adalah SPALD-T skala permukiman [18]. Adapun kerangka tahapan penapisan SPALD yang dilakukan dapat dilihat pada Gambar 1. 


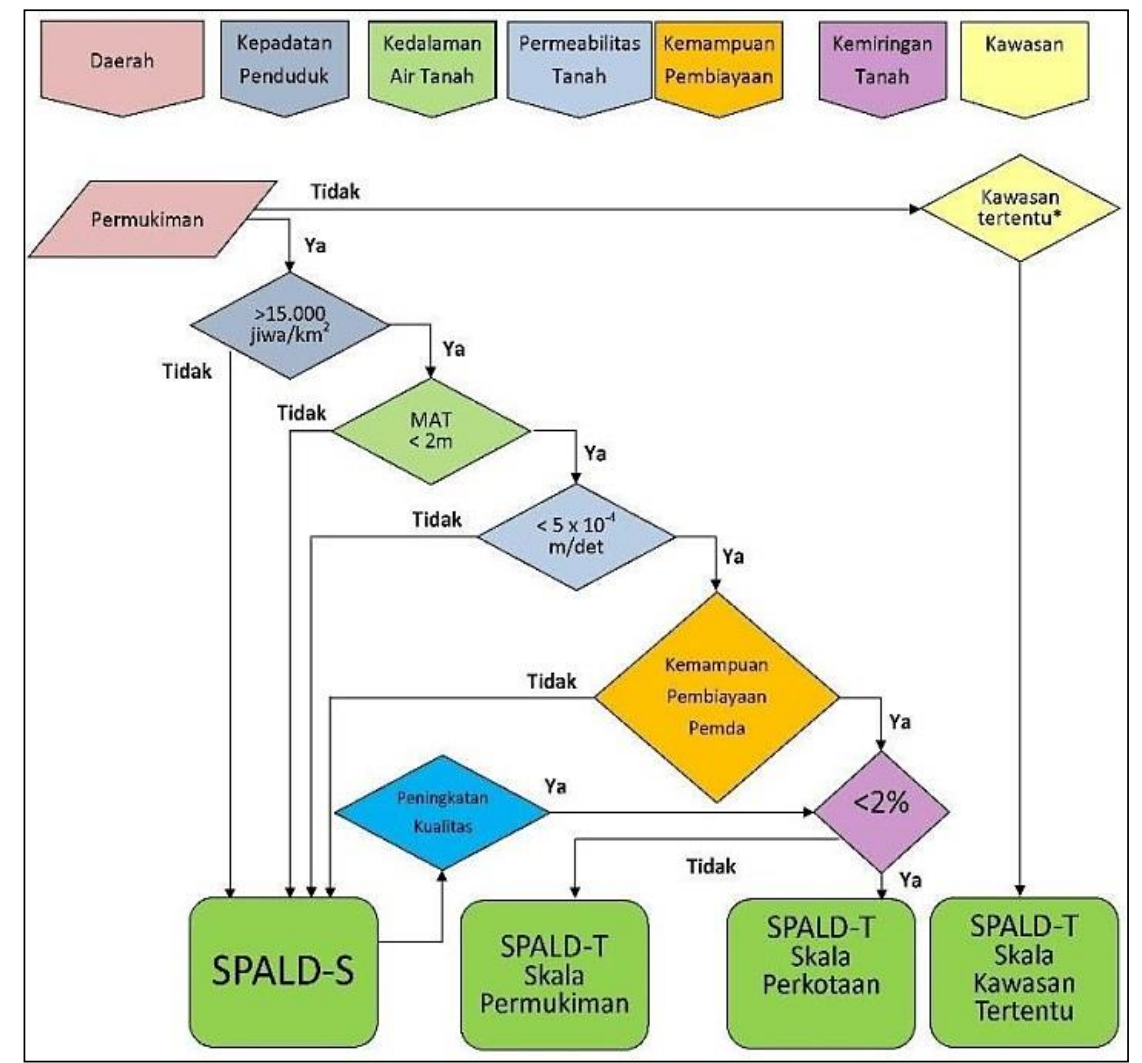

Gambar 1. Peta kerangka tahapan penapisan SPALD DAS Cibabat, Kota Cimahi Sumber: [5]

Data yang digunakan dalam penelitian ini merupakan data sekunder dari Pemerintah Kota Cimahi seperti data BPS kependudukan dan profil Sungai Cibabat Tahun 2019, dokumen RTRW, buku putih sanitasi, data topografi wilayah Kota Cimahi, dan data lainnya.

\section{Hasil dan Pembahasan}

Total jumlah kelurahan yang ada Kota Cimahi sebanyak 15 (lima belas) dimana diantaranya terdiri dari 3 (tiga) kelurahan yg masuk kedalam wilayah DAS Cibabat. Tiga kelurahan tersebut diantaranya Kelurahan Cigugur Tengah, Kelurahan Baros, dan Kelurahan Utama. Luas wilayah yang masuk kedalam DAS Cibabat dapat dilihat pada Tabel 1.

Tabel 1. Jumlah penduduk kelurahan dalam DAS Cibabat 2020

\begin{tabular}{clccc}
\hline Kecamatan & \multicolumn{1}{c}{ Kelurahan } & $\begin{array}{c}\text { Luas Dalam } \\
\mathrm{DAS}\left(\mathrm{Km}^{2}\right)\end{array}$ & $\begin{array}{c}\text { Luas Total } \\
\text { Kelurahan } \\
\left(\mathrm{Km}^{2}\right)\end{array}$ & $\begin{array}{c}\text { Luas kelurahan } \\
\text { dalam DAS }(\%)\end{array}$ \\
\hline Cimahi Tengah & Kelurahan Cigugur Tengah & 1,116 & 2,531 & $44,09 \%$ \\
Cimahi Tengah & Kelurahan Baros & 0,085 & 2,25 & $3,78 \%$ \\
Cimahi Selatan & Kelurahan Utama & 0,654 & 3,081 & $21,23 \%$ \\
\hline
\end{tabular}

Sumber: Hasil analisa, 2021

Berdasarkan Tabel 1 terlihat bahwa luas DAS Cibabat 24\% nya dari sebagian luas total wilayah kelurahan yang dilalui oleh DAS Cibabat. Kelurahan dengan wilayah terbesar dalam DAS Cibabat adalah Kelurahan Cigugur Tengah dengan luas kelurahan dalam DAS sebesar $1.116 \mathrm{Km}^{2}$ dari total luas kelurahannya sebesar $2.531 \mathrm{Km}^{2}$. Sedangkan kelurahan dengan luas wilayah terkecil yang masuk ke dalam DAS adalah Kelurahan Baros dengan luas wilayah kelurahan yg masuk dalam DAS hanya sebesar $0,65 \mathrm{Km}^{2}$ dari luas total kelurahannya .

Dalam sebuah perencanaan sistem penyaluran air limbah, jumlah penduduk dalam daerah perencanaan sangatlah penting. Jumlah penduduk penting karena pertambahannya akan berjalan seiringan dengan banyaknya air limbah di daerah perencanaan, sehingga diperlukan suatu proyeksi penduduk dalam periode 20 tahun kedepan untuk menentukan jumlah dan kepadatan penduduk dari pemilihan jenis SPALD yang akan direncanakan berdasarkan penapisanya. Dalam hal tersebut, penelitian yang dilakukan 
ini telah melakukan proyeksi jumlah dan kepadatan penduduk hingga tahun 2040 dengan metode aritmatika yang merupakan metode terbaik dan terpilih sampai dihasilkan jumlahnya.

Berdasarkan analisa proyeksi yang didapatkan, kepadatan penduduk yang masuk kedalam DAS Cibabat dilihat dari luas area kelurahan yang masuk kedalam wilayah DAS di bandingkan dengan jumlah penduduk keluarahan tersebut. Hasil perbandingan inilah yang akan menentukan kepadatan penduduk DAS Cibabat dalam menentukan jenis SPALD yang akan di terapkan

\section{Kepadatan Penduduk}

Kepadatan penduduk adalah langkah awal saat melakukan penapisan dan merupakan faktor penting dalam penentuan jenis sistem pengelolaan air limbah domestik dengan menggunakan SPALD-S atau SPALD-T. Ketentuan daftar penapisan yaitu jika peruntukan menggunakan jenis SPALD-T maka kepadatan penduduk harus lebih besar dari $150 \mathrm{jiwa} / \mathrm{ha}$ maka dapat melanjutkan analisa penapisan selanjutnya untuk SPALD-T, namun jika kepadatan lebih kecil maka pengelolaan limbah dilakukan dengan SPALD-S. Jumlah dan kepadatan penduduk proyeksi hingga 20 tahun ke depan pada masingmasing bagian kelurahan pada DAS Cibabat dapat dilihat pada Tabel 2.

Tabel 2. Jumlah dan kepadatan penduduk DAS Cibabat

\begin{tabular}{ccccccc}
\hline \multirow{2}{*}{$\begin{array}{c}\text { Tahun } \\
(\mathrm{T})\end{array}$} & \multicolumn{5}{c}{ Data Proyeksi Penduduk Dalam DAS } \\
\cline { 2 - 6 } & $\begin{array}{c}\text { Kelurahan Cigugur Tengah } \\
\text { penduduk }\end{array}$ & $\begin{array}{c}\text { Kepadatan } \\
\text { penduduk }\end{array}$ & $\begin{array}{c}\text { Delurahan Baros } \\
\text { penduduk }\end{array}$ & $\begin{array}{c}\text { Kepadatan } \\
\text { Penduduk }\end{array}$ & $\begin{array}{c}\text { Data } \\
\text { penduduk }\end{array}$ & $\begin{array}{c}\text { Kepadatan } \\
\text { Penduduk }\end{array}$ \\
\cline { 2 - 6 } & 20.998 & 18.806 & 787 & 9.255 & 9.705 & 14.840 \\
2020 & 22.499 & 20.160 & 843 & 9.921 & 10.404 & 15.908 \\
2030 & 24.118 & 21.611 & 904 & 10.635 & 11.153 & 17.053 \\
2035 & 25.855 & 23.167 & 969 & 11.401 & 11.956 & 18.281 \\
2040 & 27.716 & 24.835 & 1.039 & 12.222 & 12.817 & 19.597 \\
\hline
\end{tabular}

\section{Sumber: Pengolahan data [1]}

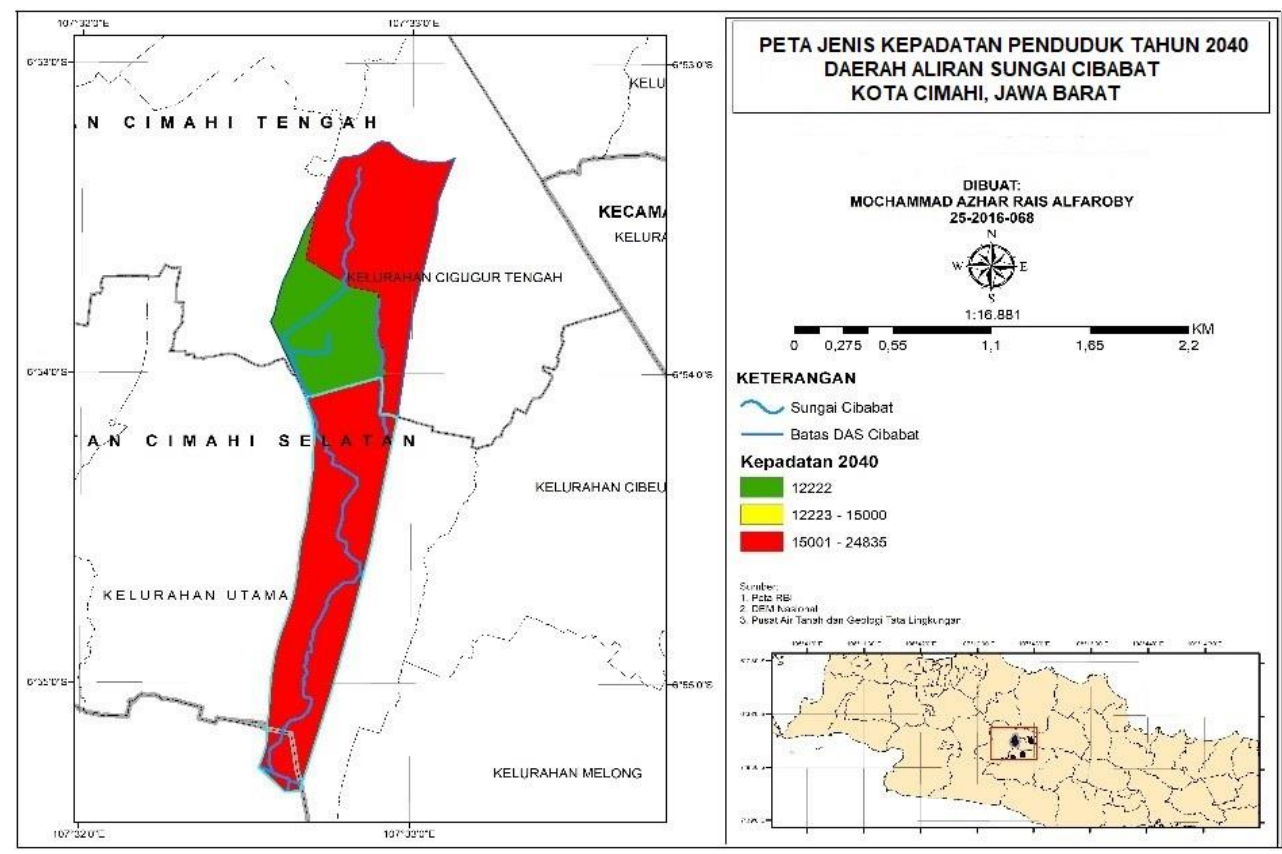

Gambar 2. Peta kepadatan penduduk DAS Cibabat

Sumber: [3]

Jenis SPALD yang akan digunakan menurut penapisan kepadatan penduduk adalah bila suatu daerah memiliki kepadatan penduduk lebih besar dari 15.000 jiwa $/ \mathrm{km} 2$ maka jenis SPALD yang digunakan adalah SPALD-Terpusat. Kepadatan penduduk yang ditentukan kedalam penapisan SPALD ialah jumlah kepadatan penduduk dari luas total keseluruhan kelurahan seperti yang terlihat pada Tabel 2. Dari hasil analisa yang disajikan pada Tabel 2, kelurahan yang memiliki kepadatan $>15.000 \mathrm{jiwa} / \mathrm{km} 2$ adalah Kelurahan Cigugur Tengah dan Kelurahan Utama dengan kepadatan penduduk masing-masing adalah $24.835 \mathrm{jiwa} / \mathrm{km} 2$ dan $19.597 \mathrm{jiwa} / \mathrm{km} 2$ pada periode perencanaan tahun 2040. Oleh karenanya, Kelurahan Cigugur Tengah dapat menggunakan jenis SPALD-Terpusat. Sedangkan untuk Kelurahan Baros yang memiliki kepadatan penduduk sebesar 12.817 jiwa/ km2 pada periode perencanaan Tahun 
2040, dapat diartikan bahwa kelurahan tersebut hanya memiliki kepadatan penduduk $<15.000 \mathrm{jiwa} / \mathrm{km} 2$. Sehingga jenis SPALD yang akan digunakan pada kedua Kelurahan Baros adalah jenis SPALD-Setempat.

\section{Kedalaman Muka Air Tanah}

Ketentuan PermenPUPR No.4/2017 menjelaskan jika lokasi perencanaan memiliki kedalaman muka air tanah $<2 \mathrm{~m}$ maka pengelolaan air limbah dilakukan dengan SPALD-Terpusat, namun jika lebih besar pengelolaan dilakukan dengan SPALD-Setempat. Penentuan muka air tanah pada DAS Cibabat yang digunakan merupakan peta cekungan air tanah yang didapat dari Pusat Air Tanah dan Geologi Tata Lingkungan [10]. Berdasarkan hasil analisis yang diperoleh, rata-rata wilayah DAS Cibabat memiliki kedalaman air tanah lebih dari 2 meter di bawah tanah, dengan kondisi air rusak pada akuifer 50-150 meter, dan untuk sebagian wilayah Kelurahan Baros dan Utama memiliki kondisi air tanah kritis dan rawan pada akuifer 50-150 meter. Gambar 3 menunjukkan mengenai kondisi cekungan air tanah di DAS Cibabat [10].

Tabel 3. Penapisan jenis SPALD-T dengan kedalaman muka air

\begin{tabular}{cccccc}
\hline Kelurahan & Kondisi & Kedalam & Kriteria & Keterangan & Kesimpulan \\
Air Tanah & MAT $(\mathrm{m})$ & Penapisan $(\mathrm{m})$ & SPALD-T & Jenis SPALD \\
\hline \multirow{4}{*}{ Cigugur tengah } & Rusak & $>55$ & $<2$ & Tidak memenuhi & SPALD-S \\
& Kritis & $35-55$ & $<2$ & Tidak memenuhi & SPALD-S \\
& Rawan & $25-35$ & $<2$ & Tidak memenuhi & SPALD-S \\
& Aman & 25 & $<2$ & Tidak memenuhi & SPALD-S \\
& Kritis & $35-55$ & $<2$ & Tidak memenuhi & SPALD-S \\
& Rawan & $25-35$ & $<2$ & Tidak memenuhi & SPALD-S \\
& Rusak & $>55$ & $<2$ & Tidak memenuhi & SPALD-S \\
& Kritis & $35-55$ & $<2$ & Tidak memenuhi & SPALD-S \\
& Rawan & $25-35$ & $<2$ & Tidak memenuhi & SPALD-S \\
\hline
\end{tabular}

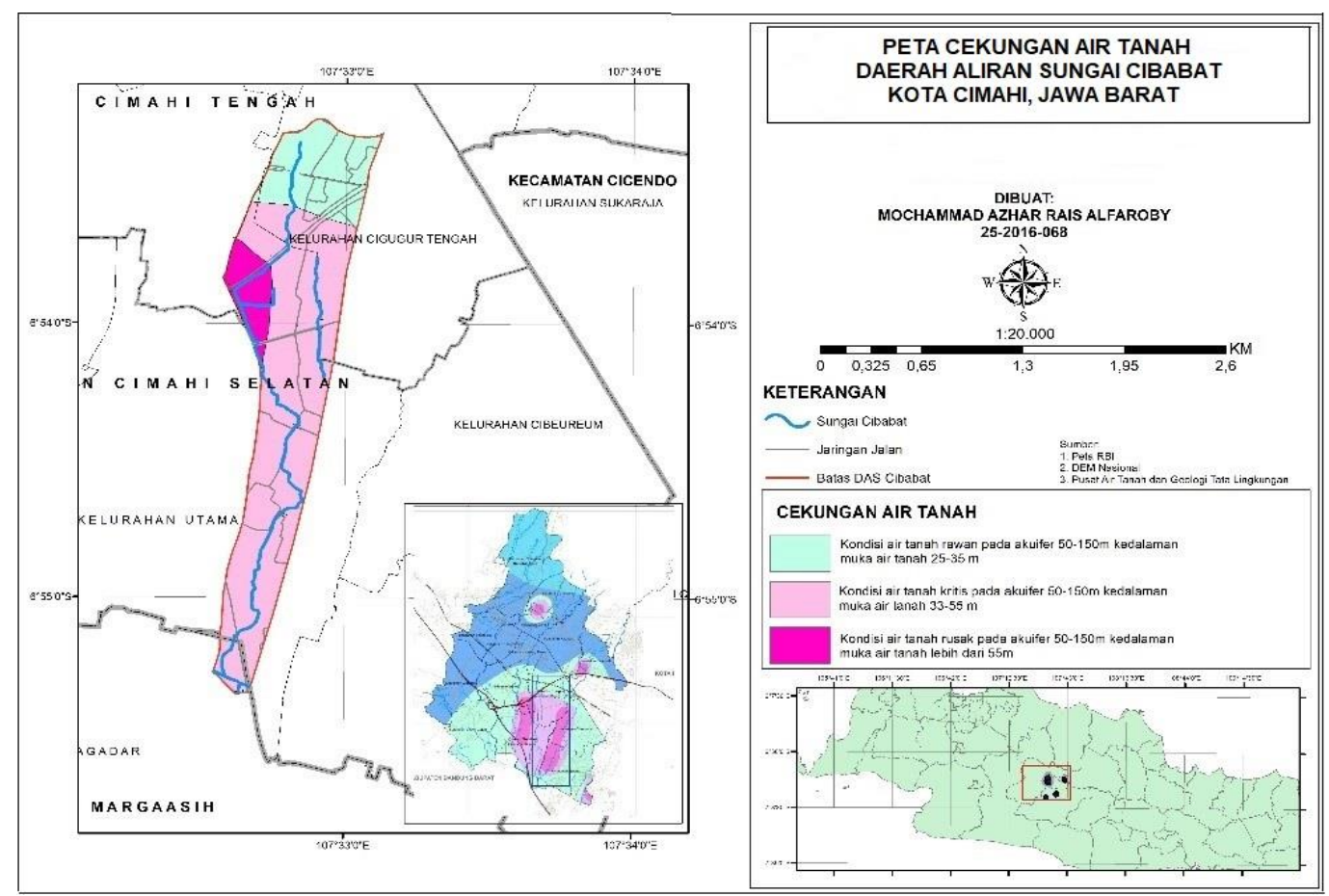

Gambar 3. Kedalaman muka air tanah DAS Cibabat Sumber: Ref. [1]

Berdasarkan Tabel 3 menunjukkan pertimbangan untuk bagian penapisan jenis SPALD dengan kedalaman muka air, wilayah DAS Cibabat dapat menerapkan jenis pengelolaan air limbah domestik jenis SPALD-Setempat, dikarenakan dari ketiga bagian wilayah kelurahan yang berada dalam DAS memiliki kedalaman muka air tanah lebih besar atau $>2$ m dengan kondisi rusak, rawan dan juga kritis, sehingga untuk penggunaan SPALD digunakan jenis SPALD-setempat. Meskipun begitu, tetap perlu dilakukan pertimbangan terhadap kriteria-kriteria lainnya sebelum menentukan jenis SPALD yang akan digunakan akhirnya. 


\section{Permeabilitas Tanah}

Kelurahan Cigugur Tengah, Baros, dan Utama merupakan wilayah yang memiliki jenis tanah yang beragam namun rata-rata jenis tanah yang mendominasi terdiri dari jenis tanah Latosol dan Aluvial yang dikategorikan adalah berbatu apung dan tufa pasir merupakan batu yang dihasilkan dari aktivitas vulkanik dan memiliki pori-pori yang besar sehingga dapat mempermudah proses penyerapan air [11]. Permeabilitas dapat dikaitkan dengan jenis batu yang menjadi penyusun wilayah DAS Cibabat. Hal ini dapat dikaitkan dengan kondisi porositas tanah. Porositas adalah proporsi ruang pori total (ruang kosong) yang terdapat dalam satuan volume tanah yang dapat ditempati oleh air dan udara, sehingga merupakan indikator kondisi drainase dan aerasi tanah [11].

Berdasarkan hasil analisis jenis tanah dan permeabilitas disimpulkan bahwa wilayah DAS Cibabat meliputi Kelurahan Cigugur Tengah, Baros dan Utama memiliki 2 jenis bebatuan yang tersebar dan tercampur dengan permeabilitas yang berbeda namun memenuhi kriteria penapisan dengan masingmasing nilai permeabilitas jenis tanah kurang dari $5 \times 10^{-4} \mathrm{~m} /$ detik. Berdasarkan penapisan layak menerapkan SPALD-Terpusat. Tabel 4 menyajikan nilai permeabilitas sesuai jenis tanah pada masingmasing kelurahan yang ada pada DAS Cibabat.

Tabel 4. Nilai permeabilitas dan jenis tanah pada wilayah DAS Cibabat

\begin{tabular}{|c|c|c|c|c|c|}
\hline \multirow[b]{2}{*}{ Jenis tanah } & \multicolumn{3}{|c|}{ Permeabilitas } & \multirow[b]{2}{*}{$\begin{array}{c}\text { Jenis } \\
\text { SPALD }\end{array}$} & \multirow[b]{2}{*}{ Keterangan } \\
\hline & $\mathrm{K}(\mathrm{cm} / \mathrm{det})$ & $\mathrm{K}(\mathrm{m} / \mathrm{det})$ & $\begin{array}{c}\text { Kriteria } \\
\text { Penapisan } \\
\text { (m/det) }\end{array}$ & & \\
\hline Latosol & 10,85 & $2,95 \times 10^{-5}$ & \multirow{4}{*}{$<5 \times 10^{-4}$} & \multirow{4}{*}{ SPALD-T } & Memenuhi \\
\hline Aluvial & $10^{-9}$ & $5,56 \times 10^{-8}$ & & & Memenuhi \\
\hline Batu apung & $2,9 \times 10^{-2}$ & $2,9 \times 10^{-4}$ & & & Memenuhi \\
\hline Tufa Pasiran & $3 \times 10^{-2}$ & $3 \times 10^{-5}$ & & & Memenuhi \\
\hline
\end{tabular}

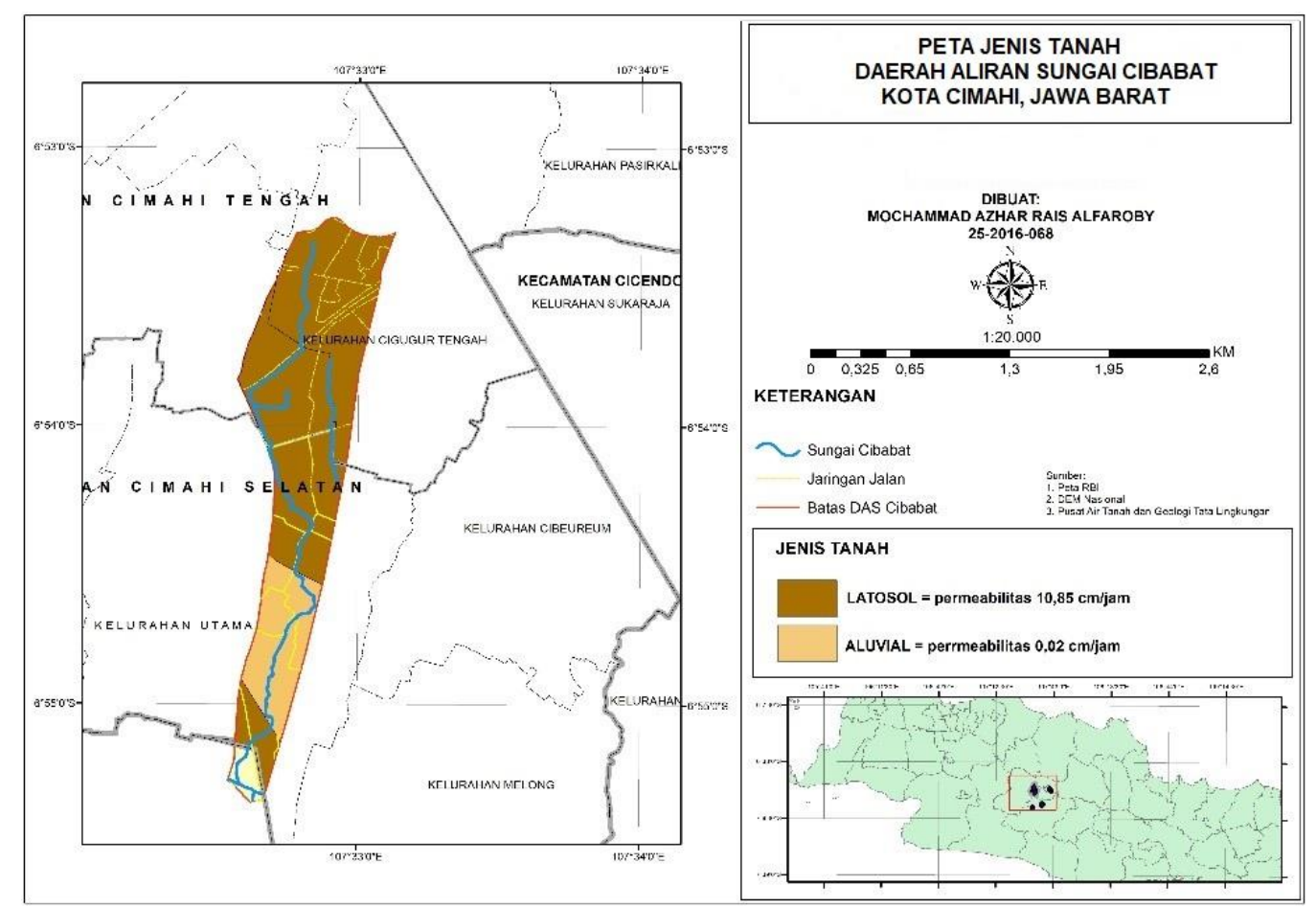

Gambar 4. Peta permeabilitas dan jenis tanah DAS Cibabat Sumber: Pengolahan data [10] [11]

\section{Kemampuan Pembiayaan}

Sesuai Dokumen Rencana Pembangunan Jangka Menengah (RPJM) Kota Cimahi Tahun 20182022 menjelaskan bahwa salah satu pencapaian prioritas pembangunan Kota Cimahi adalah meningkatkan kualitas lingkungan fisik dan non fisik dengan memanfaatkan ruang perkotaan yang efisien, berkelanjutan, bermanfaat dan berkesinambungan [12]. Sektor domestik direncanakan pengembangan sistem pengelolaan air limbah meliputi: (1) Pengembangan saluran sistem on-site di kawasan perumahan dengan tingkat kepadatan tinggi; (2) Pengembangan saluran sistem off-site baik 
untuk pengolahan limbah rumah tangga; dan (3) pengembangan 3 unit Instalasi Pengolahan Air Limbah (IPAL) komunal di Cimahi Selatan.

Pemerintah Kota Cimahi telah memiliki anggaran tersendiri untuk pengelolaan air limbah melalui Anggaran Pendapatan belanja Daerah (APBD) sejak tahun 2019, sehingga untuk kemampuan pembiayaan dalam pembuatan SPALD pemerintah dikatakan sanggup dan mampu untuk melalukan pengembangan jenis pengelolaan air limbah khususnya pada air limbah domestik. Sesuai penapisan maka kemampuan pembiayaan pemasangan perpipaan SPALD di DAS Cibabat memenuhi persyaratan dengan menggunakan SPALD-Terpusat.

\section{Kemiringan Tanah}

Kriteria kemiringan tanah yang diatur pada penapisan yaitu nilainya harus lebih besar dari dua persen untuk dapat menggunakan SPALD-Terpusat. Data kemiringan tanah pada DAS Cibabat yang digunakan berasal dari peta kemiringan lereng yang didapat dari Pusat Air Tanah dan Geologi Tata Lingkungan [10]. Tabel 5 menjabarkan topografi dan kemiringan tanah di kecamatan Cimahi Tengah dan Selatan.

Tabel 5. Topografi dan kemiringan tanah Kota Cimahi

\begin{tabular}{|c|c|c|}
\hline Kecamatan & $\begin{array}{c}\text { Kemiringan Lereng } \\
(\%)\end{array}$ & Elevasi \\
\hline Cimahi Tengah & $\begin{array}{l}\text { Datar-Landai }(0-3 \%) \\
\text { Berombak }(3-8 \%) \\
\text { Bergelombang }(8-15 \%) \\
\text { Curam }(25-45 \%)\end{array}$ & $850-700$ \\
\hline Cimahi Selatan & $\begin{array}{l}\text { Datar-Landai }(0-3 \%) \\
\text { Berombak }(3-8 \%) \\
\text { Bergelombang }(8-15 \%) \\
\text { Curam }(25-45 \%)\end{array}$ & $800-685$ \\
\hline
\end{tabular}

Berdasarkan data topografi dan kemiringan tanah pada Tabel 5, DAS Cibabat memiliki kemiringan lahan yang relatif datar-landai dengan keberadaan DAS yang berada pada dua kecamatan yang berbeda yaitu Kecamatan Cimahi Tengah dan Cimahi Selatan. Kedua daerah ini didominasi dengan kemiringan lereng lebih dari 3\%, dimana seluruh wilayahnya terdapat beberapa kondisi yang datar-landai, bergelombang, dan juga terdapat beberapa area kelurahan dengan kondisi kemiringan tanah yang curam, kemiringan tanah DAS Cibabat dapat dilihat pada Gambar 5.

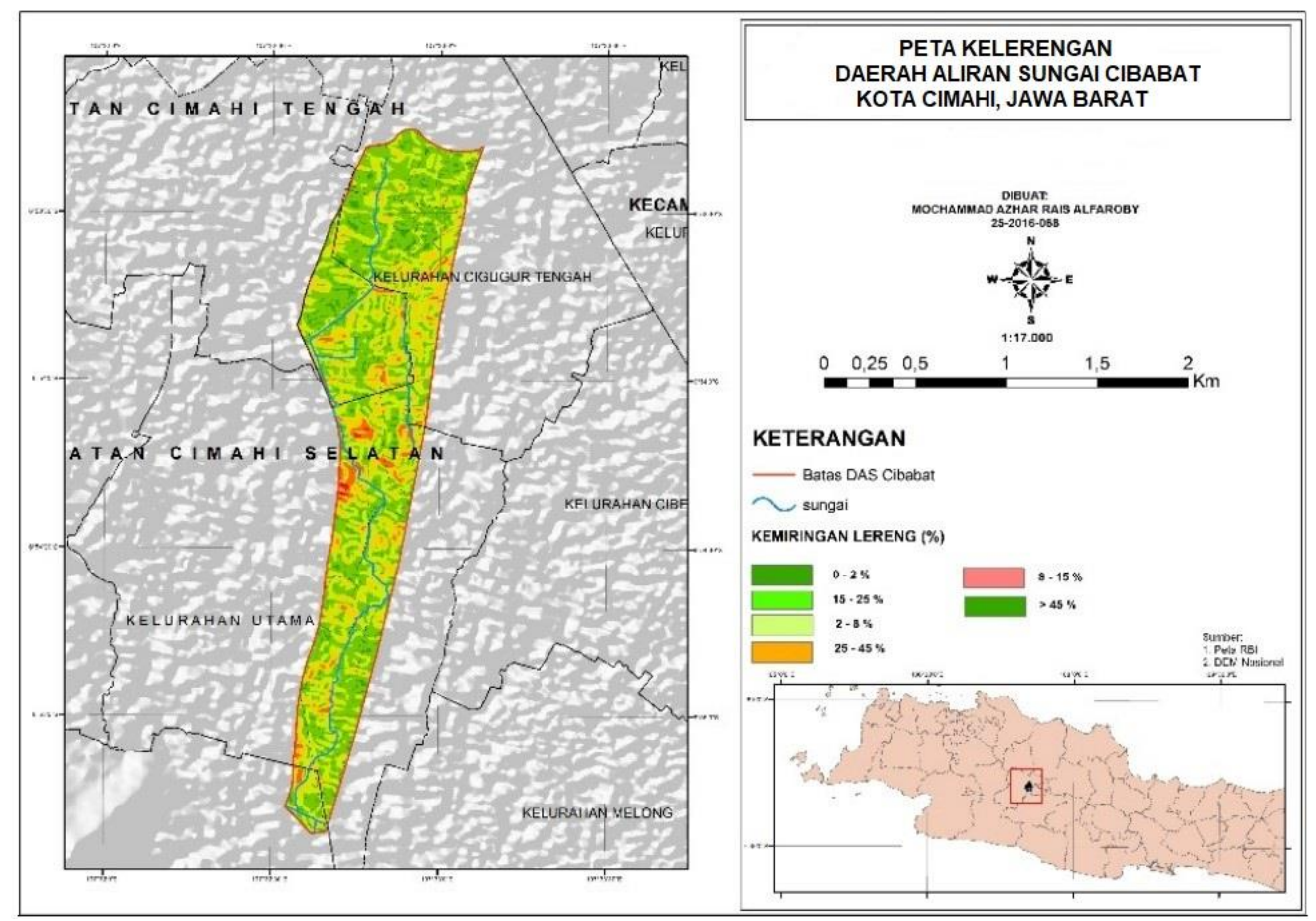

Gambar 5. Peta kemiringan tanah DAS Cibabat

Sumber: Ref. [1] 
Berdasarkan Gambar 5, terlihat bahwa Kondisi topografi DAS Cibabat didominasi kemiringan tanah lebih besar dari $2 \%$ ini akan memudahkan proses penentuan jalur dan proses pembangunan konstruksi. Suatu jalur pelayanan penyaluran air limbah yang memanfaatkan gravitasi sebagai energinya sehingga tidak diperlukan metode pemompaan dalam penyaluran menuju IPAL [13].

Untuk penentuan jenis SPALD di DAS Cibabat terdapat beberapa analisa daftar penapisan yang memenuhi dan tidak memenuhi persyaratan jenis SPALD-T disetiap kelurahan yang pada DAS Cibabat, sehingga diperlukannya pertimbangan dalam penentuan jenis SPALD yang akan terpilih. Dalam melakukan pertimbangan jenis SPALD, dilakukan kembali penapisan kumulatif dengan skoring point terbanyak yang didapatkan pada pemilihan hasil penapisan. Skor yang diperoleh terbanyak dalam penentuan penapisan jenis SPALD merupakan jenis pertimbangan SPALD yang akan terapkan. Berdasarkan hasil penapisan kumulatif dalam perencanaan selama 20 tahun ke depan sampai tahun 2040 dapat dilihat pada Tabel 6.

Tabel 6. Penapisan akumulasi jenis SPALD DAS Cibabat Tahun 2021

\begin{tabular}{lcccc}
\hline \multirow{2}{*}{ Penapisan } & \multirow{2}{*}{ Satuan } & \multicolumn{3}{c}{ Kelurahan } \\
\cline { 2 - 5 } & & Cigugur Tengah & Baros & Utama \\
\hline Kepadatan Penduduk & Jiwa/km2 & SPALD-T & SPALD-S & SPALD-T \\
Kedalaman MAT & $\mathrm{m}$ & SPALD-S & SPALD-S & SPALD-S \\
Permeabilitas & $\mathrm{m} / \mathrm{det}$ & SPALD-T & SPALD-T & SPALD-T \\
Kemampuan biaya & mampu/tidak & SPALD-T & SPALD-T & SPALD-T \\
Kemiringan Tanah & $\mathrm{m}$ & SPALD-T & SPALD-T & SPALD-T \\
SPALD-T & Nilai Skor & 4 & 3 & 4 \\
SPALD-S & & 1 & 2 & 1 \\
Kesimpulan Jenis SPALD & & SPALD-S & \\
Pertimbangan Lain Jenis SPALD & SPALD-T & SPALD-S & SPALD-T \\
\hline
\end{tabular}

Sumber: Pengolahan data [1] Pusat Air Tanah dan Geologi Tata Lingkungan [2]

Berdasarkan Tabel 6 disimpulkan bahwa penapisan pada setiap kelurahan yang ada dalam DAS Cibabat didapatkan berdasarkan pertimbangan meskipun hasil penapisan yang didapatkan mengarahkan jenis pengolahan SPALD-Setempat. Sungai Cibabat telah menunjukan tingkat pencemaran yang tinggi yang didasarkan pada daya tampung dan mutu sungai yang dikategorikan telah tercemar berat, dan telah ditimbulkannya vektor penyakit bawaan yang telah dirasakan masyarakat sekitar DAS Cibabat selama ini [15]. Kondisi sanitasi di Kota Cimahi yang kurang baik menyebabkan sistem yang tepat adalah SPALDTerpusat terutama di kelurahan dengan kepadatan tinggi yaitu Cigugur Tengah dan Utama. Periode perencanaan tahun 2020-2040 terdapat 2 kelurahan yang menerapkan jenis SPALD-Terpusat yaitu Kelurahan Cigugur Tengah dan Utama. Satu kelurahan lainnya yaitu Baros, layak menerapkan SPALDSetempat. Peta penentuan SPALD di sajikan pada Gambar 6.

Terdapat beberapa pertimbangan lain yang dapat dilakukan untuk menentukan jenis SPALD, diantaranya apabila wilayah tertentu mampu meningkatkan kualitas pengelolaan lingkungan, kemudian pertimbangan kemiringan tanah yang lebih (curam) bisa menggunakan jenis SPALD-Terpusat. dan juga pertimbangan lainnya adalah terkait ketersediaan lahan untuk membuat jenis SPALD-Terpusat dimana nantinya akan di bangun Instalasi Pengolahan Air Limbah Domestik (IPALD) pada daerah dengan lahan yang masih kosong, milik pemerintah atau milik masyarakat dengan sistem kontrak berbayar, dan nantinya akan mengalirkan air limbah domestik warga [13][14].

Pengelompokan skala pelayanan SPALD-Terpusat, ditentukan berdasarkan jumlah penduduk daerah pelayanan. jumlah penduduk yang tinggal pada daerah perencanaan minimal 20.000 maka jenis SPALD-Terpusat yang digunakan adalah SPALD-Terpusat skala perkotaan. Jumlah penduduk antara 5020.000 jiwa, maka jenis yang cocok digunakan SPALD-Terpusat skala permukiman. Kelurahan Cigugur sesuai menerapkan SPALD-Terpusat skala perkotaan dan SPALD-Terpusat skala pemukiman sesuai diterapkan di kelurahan Utama. Tabel 7 memperlihatkan jenis skala SPALD-Terpusat pada masingmasing daerah perencanaan yang telah disesuaikan berdasarkan Permen PUPR No. 4 Tahun 2017 berdasarkan jumlah penduduk hasil proyeksi tahun 2040.

Kelurahan yang menerapkan jenis SPALD-S setelah pertimbangan lebih lanjut merupakan Kelurahan Baros. Jenis SPALD-S yang digunakan adalah tangki septik komunal yang diperuntukkan 50 orang per unit. Dipilihnya jenis tangki septik komunal didasarkan pada keterbatasan lahan kosong yang ada dan juga biaya pemerintah pada anggaran pada Tahun 2040. 


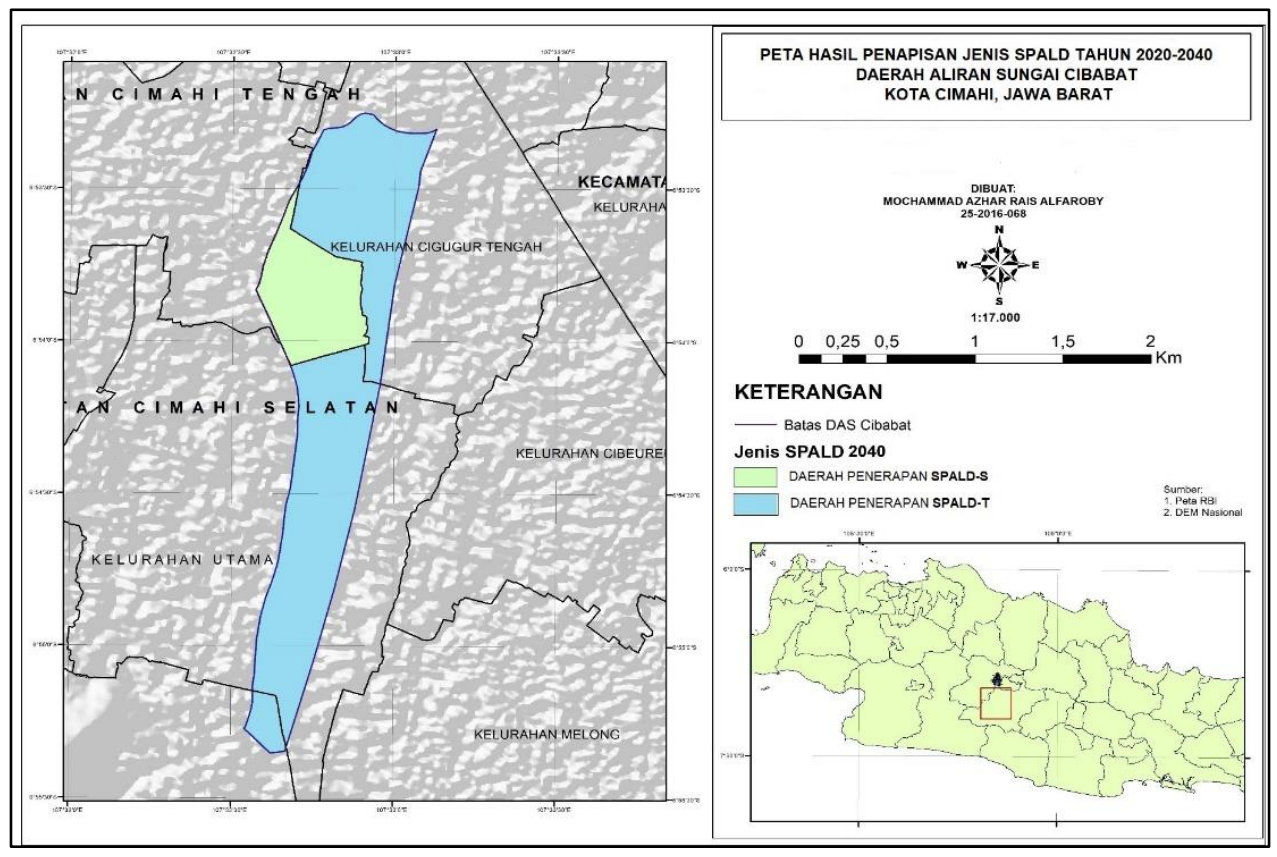

Gambar 6. Peta pertimbangan jenis SPALD pada DAS Cibabat Sumber: Analisis, 2021 Ref [1]

Tabel 7. Hasil penentuan skala jenis SPALD-T terhadap jumlah penduduk kelurahan terproyeksi tahun 2040

\begin{tabular}{lcc}
\hline \multicolumn{1}{c}{ Kelurahan } & Jumlah Penduduk & Skala SPALD-T \\
\hline Cigugur Tengah & 27.716 & Perkotaan \\
\hline Utama & 12.817 & Pemukiman \\
\hline Total Penduduk & & 40.532 \\
\hline
\end{tabular}

Sumber: Analisis, 2021. Ref [5]

Anggaran yang harus terbagi pada perencanaan sistem pengolahan air limbah di seluruh kelurahan yang ada di Kota Cimahi dalam waktu yang bersamaan, sehingga tidak memungkinkan jika harus dipilih jenis tangki septik individual pada setiap rumah di Kelurahan Baros. Banyaknya jumlah tangki septik pada Kelurahan Baros disesuaikan berdasarkan banyaknya jumlah penduduk terproyeksi pada tahun 2040, diasumsikan setiap jumlah KK terdapat 5 orang anggota keluarga. Banyaknya jumlah tangki septik menurut jumlah penduduk kelurahan Baros yang masuk ke dalam area DAS tahun 2040 dapat dilihat pada Tabel 8.

Tabel 8. Jumlah kebutuhan tangki septik berdasarkan jumlah penduduk tahun 2040

\begin{tabular}{|c|c|c|c|c|}
\hline No & Kelurahan & $\begin{array}{c}\text { Jumlah } \\
\text { Penduduk } \\
\text { Tahun } 2040\end{array}$ & $\begin{array}{l}\text { Jumlah KK } \\
\text { (asumsi 1 KK } \\
=5 \text { orang) }\end{array}$ & $\begin{array}{c}\text { Jumlah Tangki Septik } \\
\text { (unit) } 1 \text { unit }=50 \text { orang } \\
\text { pemakai }\end{array}$ \\
\hline 1. & Baros & 1.039 & 208 & 4 \\
\hline & Total & 1,039 & 208 & 4 \\
\hline
\end{tabular}

Berdasarkan analisis pada Tabel 8, jumlah tangki septik komunal akan diterapkan pada Kelurahan Baros berjumlah 4 unit pada periode perencanaan 2040. Proses kegiatan pra-konstruksi dan konstruksi sistem penyaluran dan unit tangki septik dilakukan selama 3 tahun yang dimulai pada tahun 2035 hingga 2038 yang meliputi pembangunan konstruksi 4 unit tangki septik komunal dan juga jalur pelayanan pipa dari setiap rumah penduduk perencanaan serta bangunan kontruksi Instalasi Pengolahan Lumpur Tinja (IPLT) yang dibangun di lokasi yang sama pada IPALD Kota Cimahi. Berdasarkan hasil analisis perhitungan jumlah penduduk terlayani, menunjukkan bahwa dari total jumlah penduduk DAS Cibabat di tahun 2040 yaitu 41.571 jiwa. 92\% terlayani secara SPALD-Terpusat, dan 2\% terlayani secara SPALDsetempat.

Penentuan tiga lokasi IPAL dalam perencanaan pengelolaan air limbah domestik yang ada di Kota Cimahi telah direncanakan sejak tahun 2011 dan juga telah dibuat pada RTRW Kota Cimahi. lokasi terpilih diantaranya yaitu Kelurahan Leuwigajah, Utama, dan Cibeureum. Dari ketiga lokasi IPAL yang 
telah ditentukan, dipilih 2 lokasi calon IPAL yang didasarkan pada jarak terdekat IPAL terhadap daerah perencanaan jalur induk pipa pada DAS Cibabat. lokasi calon yang direncanakan di Kelurahan Utama dan Leuwigajah, terletak di bagian selatan Kota Cimahi. Hasil hasil analisa dan perbandingan, pemilihan lokasi IPAL direncanakan di Kelurahan Utama, Kecamatan Cimahi Selatan. Pembuatan jalur mengikuti pola zona/wilayah melingkupi jalur induk sepanjang DAS Cibabat yang menyesuaikan dengan jalan-jalan utama di masing-masing kelurahan, jalur pemukiman bagi wilayah yang akan menerapkan SPALD-T skala pemukiman dan SPALD-S dengan jalur menuju 4 (empat) unit tangki septik komunal. Pembuatan jalur direncanakan menuju calon lokasi IPAL di Kelurahan Utama, Kota Cimahi. Adapun rekapitulasi peta jalur SPALD-S dan SPALD-T pada DAS Cibabat dapat dilihat pada Gambar 7.

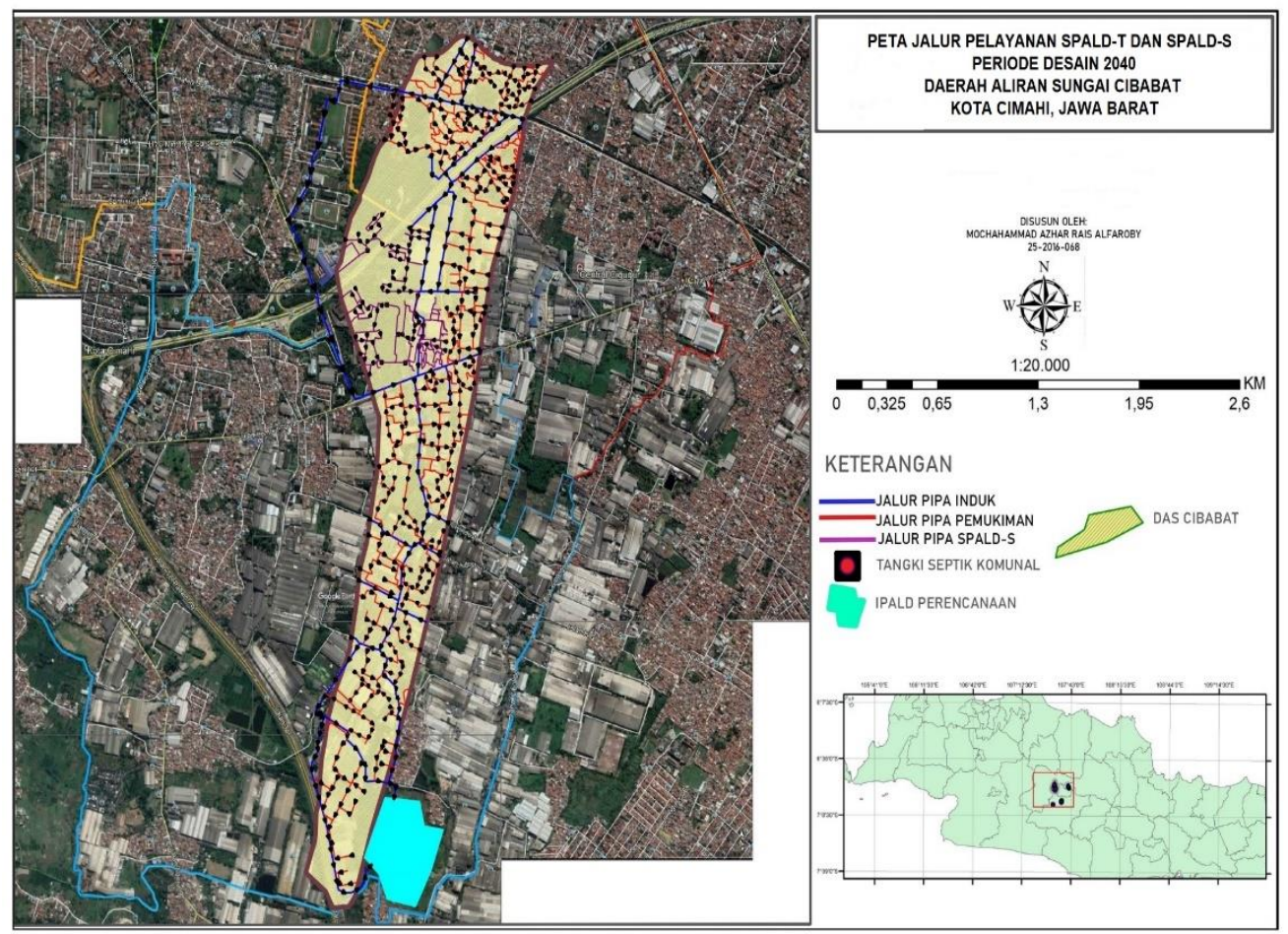

Gambar 7. Peta perencanaan jalur pelayanan SPALD pada DAS Cibabat Sumber: Pengolahan data, 2021 Ref [1]

Pengelolaan air limbah domestik yang direncanakan di DAS Cibabat akan menurunkan beban pencemaran ke Sungai Citarum. Penurunan beban pencemaran dari anak Sungai Citarum akan meningkatkan kualitas sungai induknya. Perbaikan mutu air Sungai Citarum harus dilakukan secara menyeluruh dari semua anak sungainya seperti Cikijing, Citarik, Cibaligo, Cibeureum, Cisangkan dan anak sungai lainnya [16];[17]. Pentingnya fungsi Sungai Citarum menyebabkan semua wilayah yang dilewatinya harus bersatu untuk menurunkan beban pencemaran dari sektor industri, domestik, pertanian, peternakan, pertambangan serta sumber lainnya. Sinergi yang baik antar wilayah dan sektor akan mempercepat pemulihan kualitas air Sungai Citarum dan anak-anaknya [18]; [19].

\section{Kesimpulan}

Sungai Cibabat telah menunjukan tingkat pencemaran yang tinggi yang didasarkan pada daya tampung dan mutu sungai yang dikategorikan telah tercemar berat, dan menimbulkan vektor penyakit bawaan yang dirasakan masyarakat sekitar DAS Cibabat. Maka dari itu diperlukan upaya pengendalian dan penanganan pengelolaan air limbah domestik agar tidak hilang fungsi ekosistem sungai sebagaimana seharusnya. Upaya penanganan yang tepat berdasarkan analisa yang mengacu terhadap Permen PUPR No. 4 tahun 2017 adalah dapat berupa penerapan SPALD-Terpusat dan SPALD-Setempat yang dilakukan pada masing-masing kelurahan dalam DAS Cibabat. Penanganan ini sesuai dengan analisa perencanaan yang telah dilakukan sehingga diharapkan mampu menurunkan konsentrasi pencemar dan memperbaiki kualitas air Sungai Cibabat. Dalam hasil analisa Penentuan SPALD pada DAS Cibabat diperoleh 2 kelurahan yang menggunakan SPALD-Terpusat dan kelurahan lainnya yang menerapkan SPALDSetempat. Sesuai dengan pengelompokan pelayanan skala SPALD-Terpusat berdasarkan hasil analisa diperoleh jenis pelayanan SPALD-Terpusat skala perkotaan diterapkan pada Kelurahan Cigugur tengah, sedangkan untuk Kelurahan Utama diperoleh pelayanan penerapan jenis SPALD-Terpusat skala 
pemukiman dalam pengolahannya. Untuk Kelurahan Baros dengan penerapan pengolahan air limbah jenis SPALD-Setempat digunakan unit tangki septik komunal dalam pengelolaannya untuk mengefisienkan biaya yang dikeluarkan dalam pengelolaan air limbah domestik. Berdasarkan hasil analisa terdapat 4 unit tangki septik komunal yang dapat diterapkan pada kelurahan Baros yang diperuntukan untuk $52 \mathrm{kk}$ pada setiap unitnya dalam mengolah air limbah domestiknya.

\section{Daftar Pustaka}

[1] Pemerintah Kota Cimahi. (2020) Dinas Lingkungan Hidup Kota Cimahi. Dokumen Informasi Kinerja Lingkungan Hidup (DIKPLH Kota Cimahi, 2020) Buku II Laporan Utama Dokumen Informasi Kinerja Lingkungan Hidup Daerah. Kota Cimahi. Jawa Barat.

[2] Anggraini. Y. dan Wardhani. E. (2021) Studi Mutu Air Sungai Cibaligo Kota Cimahi Provinsi Jawa Barat dengan Metode Indeks Pencemar. Jurnal Serambi Engineering. 6 (1). 1478-1487.

[3] Hermawan. Y. I dan E. Wardhani. E. (2021). Analisis Dampak Limbah Domestik terhadap Kualitas Air Sungai Cibeureum, Kota Cimahi Prosiding Simposium Nasional Teknologi Infrastruktur (SNTI) Universitas Gajah Mada. Yogyakarta. Indonesia

[4] Rosmeiliyana, \& Wardhani. E. (2021). Perhitungan Status Mutu Air Sungai Cisangkan Kota Cimahi Provinsi Jawa Barat. Prosiding Simposium Nasional Teknologi Infrastruktur (SNTI) UGM. ISBN: 978-623-91262. 604-611.

[5] Pemerintah Republik Indonesia. (2017). Peraturan Menteri Pekerjaan Umum dan Perumahan Rakyat No 4 Tahun 2017 Tentang Penyelenggaraan Sistem Pengelolaan Air Limbah Domestik. Jakarta. Indonesia

[6] Kusumawardhani, A.A, Wardhani, E, dan Halomoan, N. (2018). Penentuan Sistem Pengelolaan Air Limbah Domestik Di Kecamatan Bekasi Timur, Kota Bekasi. Jurnal EnviroSan: 1(1).

[7] Uyun, Q, Wardhani, E, dan Halomoan, N. (2019) Pemilihan Jenis Sistem Pengelolaan Air Limbah Domestik di Kecamatan Bekasi Selatan. Jurnal Rekayasa Hijau. 2(3). 157-168.

[8] Wiguna, A.S, Wardhani, E, dan Halomoan, N. (2019). Penapisan Perencanaan Sistem Penyaluran Air Limbah Domestik Kecamatan Beji, Kota Depok. Jurnal EnviroSan: 2(2)

[9] Pemerintah Kota Cimahi. (2020). Balai Pusat Statistik. Kota Cimahi Dalam Angka. Cimahi. Indonesia

[10] Pemerintah Republik Indonesia, (2020) Peta Cekungan Air Tanah Cekungan Bandung. Pusat Air Tanah dan Geologi Tata Lingkungan. Bandung. Indonesia

[11] Sunarwan. B. (2014). KarakterisasiI Phisik Air Tanah Dan Identifikasi Pemunculan Mata Air Pada Akuifer Endapan Gunung Api (Studi Kasus: Endapan Gunungapi Tangkuban perahu di Cekungan Bandung). Jurnal Teknologi, Volume II(24), 19

[12] Pemerintah Kota Cimahi (2020). Dokumen Rencana Pembangunan Jangka Menengah (RPJM) Kota Cimahi Tahun 2018-2022. Cimahi. Indonesia

[13] KemenPUPR. (2016). Buku 3 Sistem Pengelolaan Air Limbah Domestik - Terpusat Skala Permukiman. Jakarta: Direktorat Pengembangan Penyehatan Lingkungan Permukiman.

[14] Samsuhadi. (2012). Tata Cara Pemilihan Lokasi IPLT dan IPAL dengan Menggunakan Sistem Skor. Jurnal Teknik Lingkungan (Edisi Khusus "Hari Lingkungan Hidup), 157-168.

[15] Pemerintah Kota Cimahi. (2020) Badan Perencanaan dan Pembangunan Daerah Kota Cimahi. Dokumen Buku Putih Sanitasi Kota Cimahi. Kota Cimahi. Jawa Barat.

[16] Eka Wardhani. E dan Sulistiowati, L.A (2018). Kajian Daya Tampung Sungai Citarik Provinsi Jawa Barat. Jurnal Rekayasa Hijau. 2(2).147-155

[17] Sulistiowati, L.A dan Wardhani. E. (2018). Kajian Dampak Pembuangan Air Limbah Industri PT. X Terhadap Sungai Cikijing di Provinsi Jawa Barat. Rekayasa Hijau: Jurnal Teknologi Ramah Lingkungan. 2(1).20-30

[18] Arinda. A dan Wardhani. E. (2018) Analisis Profil Konsentrasi Pb di Air Waduk Saguling. Rekayasa Hijau: Jurnal Teknologi Ramah Lingkungan. 3(2).213-219.

[19] Wardhani. E, Notodarmojo. S, dan Roosmini. D. (2017) Heavy Metal Speciation in Sediments in Saguling Lake West Java Indonesia. International Journal of GEOMATE ISSN: 2186-2990 Japan Bulan Juni 2017 Vol 12 Issue 34 pp 146-151.

[20] Ranty Christiana, Ika Muthya Anggraini, dan Hezliana Syahwanti (2020). Analisis Kualitas Air dan Status Mutu Serta Beban Pencemaran Sungai Mahap di Kabupaten Sekadau Kalimantan Barat. Jurnal Serambi Engineering, Volume V, No. 2, April 2020 hal 941-950 
[21] Yeggi Darnas, Adian Aristia Anas, dan M Akbar Ardiansyah Hasibuan (2020). Pengendalian Air Lindi Pada Proses Penutupan TPA Gampong Jawa Terhadap Kualitas Air Sumur Serambi Engineering, Volume V, No. 3, Juli 2020 hal 1165-1176 